\title{
Estimating Trends and Return Periods of Daily Extreme Precipitation Associated with Tropical Cyclones in the Core North American Monsoon
}

\author{
Omar Llanes Cárdenas ${ }^{1}$, Mariano Norzagaray Campos ${ }^{1 *}$, Patricia Muñoz Sevilla ${ }^{2}$, \\ Rosario Ruiz Guerrero ${ }^{3}$, Héctor A. González Ocampo ${ }^{1}$, María N. Herrera Moreno ${ }^{1}$ \\ ${ }^{1}$ Instituto Politécnico Nacional, Centro Interdisciplinario de Investigación para el Desarrollo Integral Regional unidad \\ Sinaloa (CIIDIR-IPN-Sinaloa), Boulevard Juan de Diós Bátiz Paredes 250, Guasave, Sinaloa, México \\ ${ }^{2}$ Instituto Politécnico Nacional, Centro Interdisciplinario de Investigaciones y Estudios sobre Medio Ambiente y \\ Desarrollo (CIIEMAD), Calle 30 de Junio de 1520 s/n, barrio la Laguna Ticomán C.P. 07340, \\ Del. Gustavo A. Madero, Ciudad de México, México \\ ${ }^{3}$ Instituto Politécnico Nacional, Centro de Investigación e Innovación Tecnológica (CIITEC), \\ Cerrada de Cecati s/n. Col. Santa Catarina, Azcapotzalco, Ciudad de México, México, C.P. 02250
}

Received: 22 May 2016

Accepted: 11 July 2016

\begin{abstract}
The largest number of tropical cyclones (TCs) is generated in the northeastern Pacific Basin. These storms can produce extreme precipitation (EP) in northwestern Mexico, causing loss of life and environmental damage. It is important to understand the dynamics that cause the EP associated with TCs, since most human activity requires planning to adjust to the dynamics of local climate changes. Therefore, in this work the goal was to estimate the trends and return periods of the average annual daily extreme precipitation (AADEP; 95th percentile, P95) in the June-September season in the core North American monsoon. To do this, daily precipitation data from 1961 to 2000 from 48 climate computing (CLICOM) weather stations located in the core of the North American monsoon were used to determine AADEP:

1. Non-parametric trends with Mann-Kendall tests and Sen's slope estimator.

2. Linear trends of annual averages of 95 (P95) and 99 (P99) percentiles with the least squares method.

3. Return periods with the Gumbel frequency distribution function. The results disclose a significant upward trend in the intensity of P95 increases in mountain stations, which may be related to a greater contribution of precipitation associated with TCs.

The seasonal contribution of P95 in coastal stations and the total monsoon precipitation did not show statistical significance at $\alpha=0.05$. The return periods of P95 associated and not associated with TC's from 2005 to 2500 were calculated. Return periods of P99 have been rising since 2010 and will continue to 2500 . For P95 events associated with TCs, the anomalies are expressed with synoptic conditions of simultaneous positive anomalies in the Pacific Decadal Oscillation (+PDO), negative anomalies in the
\end{abstract}

*e-mail: mnorzacam@yahoo.com.mx 


\begin{abstract}
Atlantic Multidecadal Oscillation (-AMO), weak La Niña in the eastern equatorial Pacific, positives in Caribbean Sea temperatures ( $\left.\mathrm{SST}>28.5^{\circ} \mathrm{C}\right)$ and a strong land-sea thermal contrast in northwestern Mexico. The synoptic conditions were created two weeks before the start of TCs. This work sheds new light on the dynamics of return periods of EP and P95 trends associated with TCs, and on current and future simultaneity between anomalies of the +PDO and -AMO, which are essential characteristics for knowledge of TC for one of the regions most affected by these phenomena worldwide.
\end{abstract}

Keywords: Pacific Decadal Oscillation, return periods, P95th percentile, tropical cyclones

\section{Introduction}

Mexico is one of the countries most affected by tropical cyclones (TCs). In 1999 the highest number of casualties (480) occurred due to hydroclimatic phenomena such as average annual daily extreme precipitation (AADEP) $(\geq$ 95th percentile, $\geq$ P95) and TCs. The largest number of TC's in the world occurs in the northeastern Pacific basin [1], and the core North American monsoon (CNAM) is characterized by a climate that is arid and semiarid with the greatest rainfall variability in the North American monsoon (NAM) [2-3] (Fig. 1). In coastal and mountainous areas in particular, the AADEP can cause a high risk of erosion and loss of soil nutrients, floods, and human casualties [4-5]. In the CNAM the main economic activities (agriculture and industry) are planned and organized taking into account seasonal precipitation in summer (June-September), when about $70 \%$ of total annual precipitation falls. It is one of the most important sources of moisture, which makes the states located in this region (Sinaloa and Sonora) the most productive agricultural region of Mexico. This area has 10 dams for irrigation, power generation, and domestic water supply [6]. AADEP in the CNAM can be caused by the occurrence of positive anomalies of the Pacific decadal oscillation (+PDO) simultaneously with negative anomalies of the Atlantic multidecadal oscillation (-AMO) given the convective activity from monsoons caused by a strong land-sea thermal contrast and surface heating of moist air along the western slope of the Sierra Madre Occidental $\left(289,000 \mathrm{~km}^{2}\right.$, length $1,400 \mathrm{~km}$, width $150 \mathrm{~km}$, elevation 500-3,500 m a.s.1., and average elevation 2,440 $\mathrm{m}$ a.s.1.) [7-9]. Increases in positive anomalies of relative humidity, surface temperature, SST and negative anomalies of radiation are environmental phenomena that can take place in the NAM and can cause the highest precipitations in the CNAM [1013], which is common during the summer and influenced by the NAM and events from TCs. Recently, it has been argued that one of the biggest impacts of climate change will result from increased AADEP with return periods that can happen at any time, anywhere on the planet [14]. Within the study area, in northwest Mexico, according to [6], for the period 1962-2013, significant upward trends in temperature have been identified, which could lead to increased trends of AADEP and promote adjustments in scheduling and organization of the economic activities in the region, in search of hydrological-food sustainability [15]. Undoubtedly, there are indicators of regional and local climate changes to which society must adapt, but first these changes must be understood in order to adjust to the new mechanisms of life. Given the issues raised, the goal of this work was to estimate trends and return periods of AADEP in the CNAM and examine the roles of anomalies in SST $\left(\mathrm{SST}_{\mathrm{an}}\right)$, surface temperature $\left(\mathrm{Stemp}_{\mathrm{an}}\right)$, Pacific decadal oscillation and Atlantic multidecadal oscillation $\left(\mathrm{PDO}_{\text {an }}\right.$ vs. $\left.\mathrm{AMO}_{\text {an }}\right)$, geopotential height to

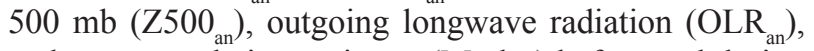
and average relative moisture ( $\mathrm{Mrel}_{\text {ave }}$ ) before and during the beginning of TC events in the northeastern Pacific.

\section{Materials and Methods}

\section{Study Area}

Out of a total of 69 weather stations of the climate computing (CLICOM) database for the period 1903-2011, only a dataset for the period from 1961 to 2000 from 48 weather stations was used (25 in Sinaloa, 13 in Sonora, and 10 in Chihuahua). Thirty weather stations (21 in Sinaloa, eight in Sonora, and one in Chihuahua) at elevations ranging from 4 to $482 \mathrm{~m}$ a.s.l. are located in flood plain areas $(\leq 500 \mathrm{~m}$ a.s.l.) and 18 weather stations (four in Sinaloa, five in Sonora, and nine in Chihuahua) with elevations ranging from 521 to $2,279 \mathrm{~m}$ a.s.l. are located in mountainous areas $(>500 \mathrm{~m})$. The period of time selected for analysis was justified in that only these weather stations met the requirement of a minimum percentage of daily precipitation data available $(\geq 95 \%)$ and absence of errors (Fig. 1). A visual inspection was used to compare values with data from neighboring stations $(\leq 25 \mathrm{~km})$, in order to validate the presence of outliers and analyze the information characteristic of the presence of TCs; only the values that were not associated with TCs were rejected.

Table 1 shows the precipitation distribution at CNAM weather stations in a downward bias with respect to elevation, which also was identified by $[11,16]$.

\section{Average Annual Daily Extreme Precipitation (AADEP)}

Summer AADEP (1 June to 30 September) was characterized for each of the 48 weather stations using the criteria of [17-18], which state that the precipitation associated with TCs are derived from a storm center located $\leq 550 \mathrm{~km}\left(5^{\circ}\right.$ latitude) from the perimeter of the 


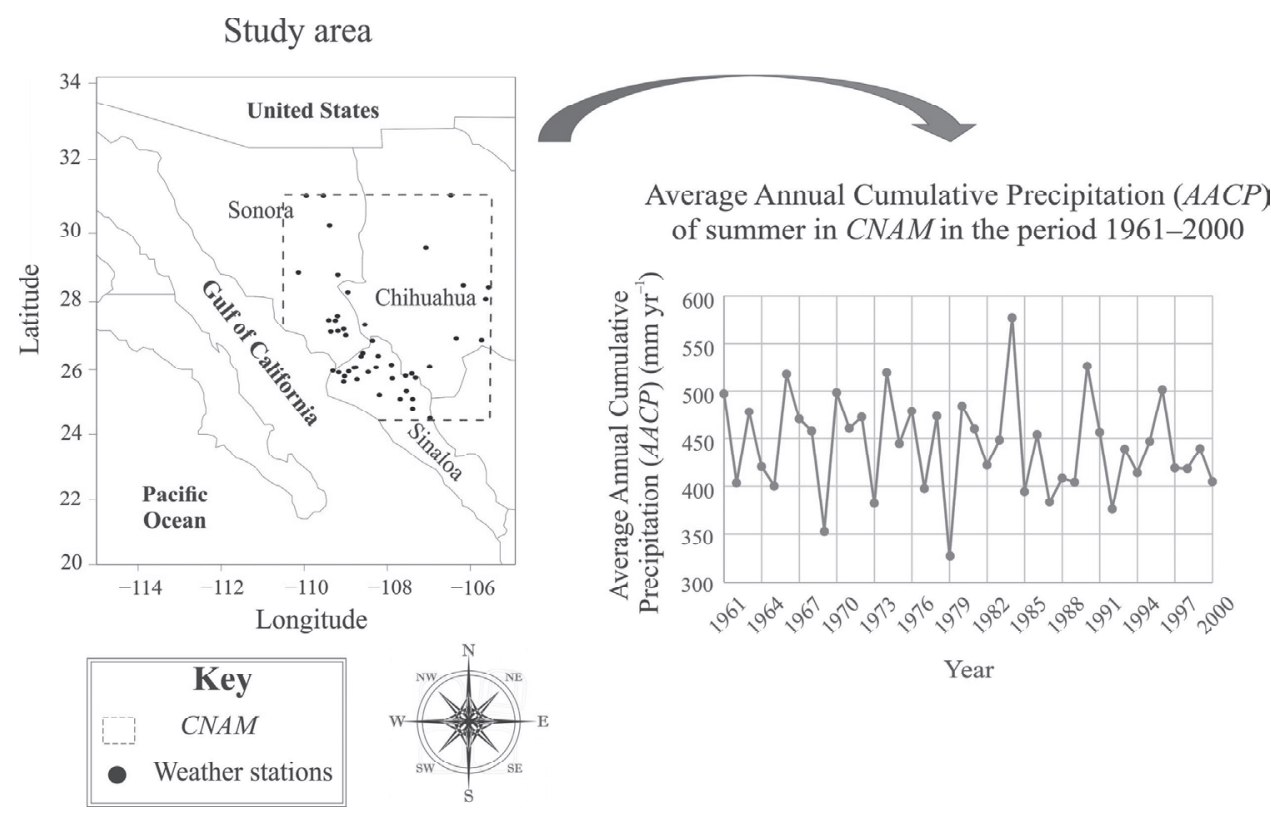

Fig. 1. Location of the study area and summer average annual cumulative precipitation (AACP) in 1961-2000 (mm $\left.\mathrm{yr}^{-1}\right)$.

CNAM. On this basis, a classification of the precipitation as associated or not associated with TCs was constructed. To do so, the trajectories of the eastern Pacific TCs were obtained from the Unisys data set (http://weather.unisys. com/hurricane/e_pacific/index.html) and were verified against the database of the National Hurricane Center (www.nhc.noaa.gov/pastall.shtml). Moreover, although the trends of AADEP associated and not associated with TC's were estimated for the period 1961-2000, only data since 1971 were analyzed separately, because the data since 1970 are more reliable, since from that time forward the intensity has been estimated by the Dvorak technique based on satellite imagery [19].

$$
\begin{aligned}
& \text { 95 }{ }^{\text {th }} \text { Percentile (P95), 99 }{ }^{\text {th }} \text { Percentile (P99), } \\
& \text { and PDO and AMO Trends }
\end{aligned}
$$

To identify and quantify the non-parametric trend of the contribution and intensity of P95 in coastal and mountain sites, the Mann-Kendall [20] methods were applied using

Table 1. Geographical characterization and average annual cumulative precipitation (AACP) of the weather stations in the study area during 1961-2000.

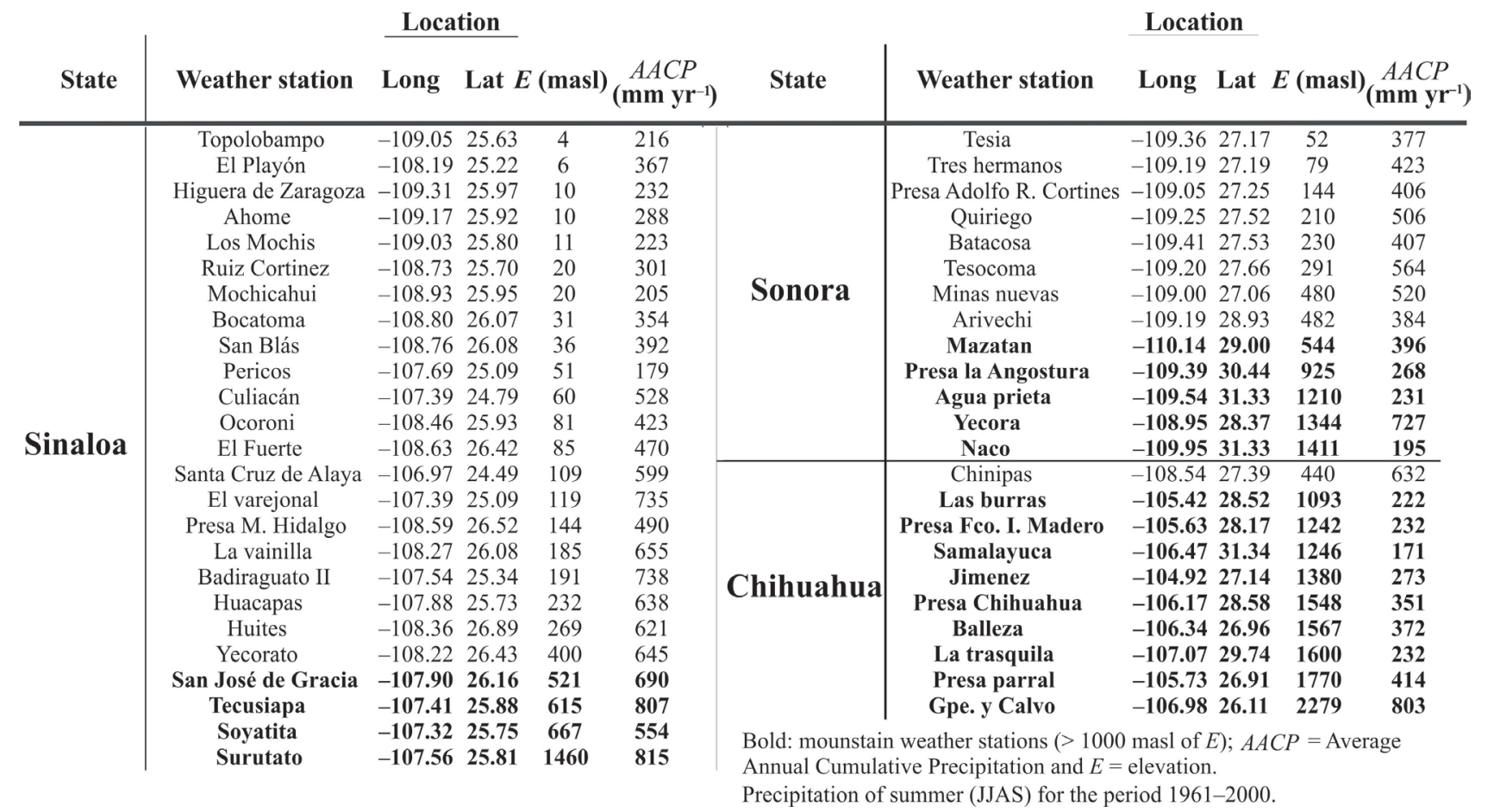


the paleontological statistics (PAST) computer program version 3.08 developed by [21], and Sen's slope method $[6,22]$ using Microsoft Excel version 2013. In coastal and mountain weather stations, linear trends of the contribution and intensity of average P95 associated and not associated with TCs, as well as trends in PDO and AMO anomalies, were calculated by the least squares method. The level of statistical significance used in all processes was $\alpha=0.05$ (95\%).

\section{Average Annual Daily Extreme Precipitation (AADEP) Return Periods}

To calculate the return periods of events associated and not associated with TCs, the Gumbel distribution function was applied, since according to [23-24], this is the distribution function most recommended for extreme precipitation values due to its high statistical reliability [25]. For processing this function we used Microsoft Excel version 2013.

\section{Synoptic Conditions Associated with P95 of TCs}

To examine the role played by $\mathrm{SST}_{\text {an }}$ at the beginning of AADEP events, optimal data interpolation was used on the weekly and satellite SST merged dataset (OISSTV2) [26], with a resolution of one degree for data available since 1981. The data reported in the OISSTV2 system, specifically for the Gulf of California, were analyzed with some discretion because they do not have complete resolution. In addition, anomalies of surface temperature $\left(\right.$ Stemp $\left._{a n}\right)$, geopotential height to $500 \mathrm{mb}\left(\mathrm{Z500}{ }_{\mathrm{an}}\right)$, outgoing longwave radiation $\left(\mathrm{OLR}_{\mathrm{an}}\right)$, and average relative moisture $\left(\mathrm{Mrel}_{\text {ave }}\right)$ were analyzed. These were obtained from the reanalysis database of the National Center for Environmental Prediction/National Center for Atmospheric Research (NCEP-NCAR) [27] for 19812000, which was constructed of compounds of average daily atmospheric variables NOAA/CDC (www.cdc.noaa. gov/Composites/Day).

\section{Statistical Validation}

Using a significance level of $\alpha=0.05$ (95\%) and value of $\mathrm{R}^{2}<1$, a linear regression was applied to AADEP between the calculated grouped $\mathrm{P}_{\text {calc }}$ of weather stations and the observed $\mathrm{P}_{\text {obs }}$ obtained from the processed data (daily average compound of the NOAA/CDC) for 19812000. Before performing linear regression, the Pearson type III normality test was applied to determine the normality of both groups. This test was used because it is
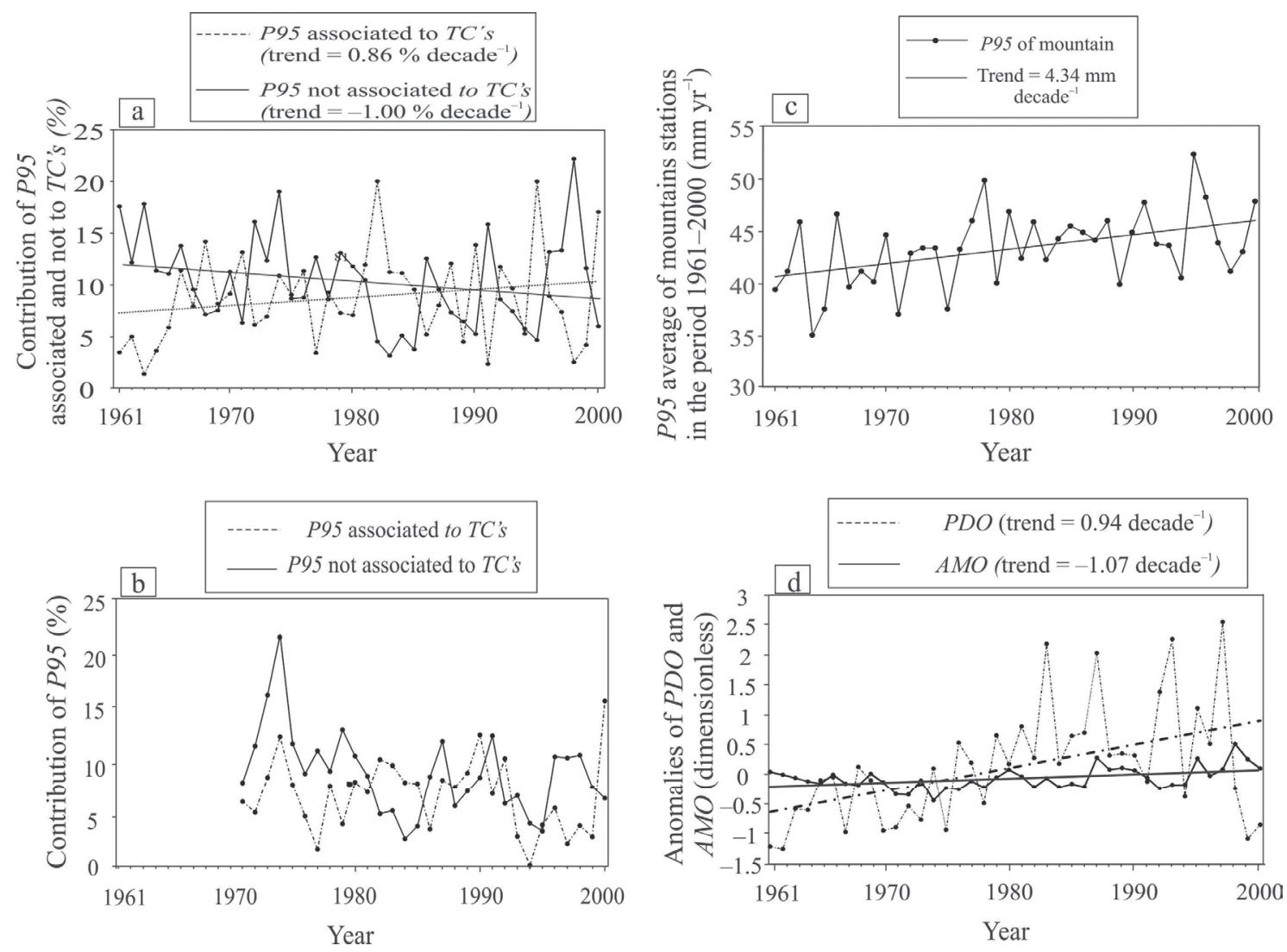

Fig. 2. a) average contribution of P95 associated and not associated with TCs in coastal and mountain stations in the period 1961$2000(\%)$, b) average contribution of P95 associated and not associated with TCs in mountain stations in 1971-2000 (\%), c) average contribution of the intensity of P95 in mountain stations in 1961-2000 (mm decade $\left.{ }^{-1}\right)$, and d) anomalies of PDO vs. AMO in 1961-2000 (dimensionless). 
one of the most powerful tests of normality when climatic data are used [28].

\section{Results and Discussion}

\section{Average Annual Daily Extreme Precipitation (AADEP)}

According to [5], P95 and P99 are important for identifying extreme precipitation over a minimum threshold. The minimum P95 and P99 thresholds associated with TCs were $24.20 \mathrm{~mm}$ day $^{-1}$ and $40.94 \mathrm{~mm} \mathrm{day}^{-1}$, respectively. The minimum thresholds of P95 and P99 not associated with TCs were $25.45 \mathrm{~mm}_{\text {day }}{ }^{-1}$ and $36.48 \mathrm{~mm} \mathrm{day}^{-1}$, respectively. The averages of the thresholds in the coastal stations not associated with TCs were $50.20 \mathrm{~mm} \mathrm{day}^{-1}$ and $85.28 \mathrm{~mm}_{\text {day }}{ }^{-1}$, respectively, and in coastal stations associated with TCs $54.30 \mathrm{~mm}$ day $^{-1}$ and $87.53 \mathrm{~mm}$ day $^{-1}$. These percentiles in mountain resorts not associated with TCs were $34.43 \mathrm{~mm}_{\text {day }}{ }^{-1}$ and $54.60 \mathrm{~mm}$ day $^{-1}$, respectively; and in the stations associated with TCs $36.58 \mathrm{~mm}^{-1 a y^{-1}}$ and $53.74 \mathrm{~mm} \mathrm{day}^{-1}$. The results show that the coastal stations had the percentiles with the highest values, and they decrease with increased elevation, which also was identified by [13] for the same study area (Fig. 2a and Table 1). This bias is attributed to the complexity and diversity of the spatial distribution of precipitation in this large area [29], which is mainly produced by the topography variables (elevation, slope, and aspect). The result is indicative of the presence of strong climate gradients that are not usually identified or are difficult to capture with precise measurements from the weather stations. Moreover, this bias is attributed to the fact that in the stations in high mountain areas, the density of the monitoring network is usually low, mainly due to difficult access to these areas [30-31].

\section{5 ${ }^{\text {th }}$ Percentile (P95), 99 $9^{\text {th }}$ Percentile (P99), and PDO and AMO Trends}

The average annual cumulative precipitation did not show a significant non-parametric trend. This is similar to what was reported by [6], who found that of a total of 16 weather stations in the core of the North American monsoon system, only two stations had a significant decreasing trend in cumulative annual precipitation (Sinaloa $=-9 \mathrm{~mm} \mathrm{yr}^{-1}$ and Sonora $=-8 \mathrm{~mm} \mathrm{yr}^{-1}$ ), and one weather station had a significant increasing trend in cumulative annual precipitation $\left(\right.$ Chihuahua $\left.=15 \mathrm{~mm} \mathrm{yr}^{-1}\right)$. Precipitation associated with TC's showed an upward linear trend since 1978 with contribution percentages of $\mathrm{P} 95$ ranging from $2.34 \%$ in 1991 to $20.03 \%$ in 1982 (Fig. 2b). These upward trends from 1978 to 1991 are directly proportional to the rates of precipitation in the study area and therefore the magnitudes tending to increase in positive slopes are indicative of records with the highest level of precipitation [32-33]. One can therefore say that linear patterns of increase on slopes indicate drastic and heavy rates of precipitation and are associated with changes in precipitation and temperature that can be associated with intense hurricanes. An event that validates these observations is Hurricane Paul, which occurred in 1982 (Fig. 2c). This was associated with a simultaneous higher occurrence of positive anomalies of PDO (+PDO) and negative anomalies of AMO (-AMO) since 1976 (Fig. 2d), which, according to [9, 34-35], is a phenomenon that generates heavy precipitation in northwestern Mexico. Since 1975, a decrease was observed in the contribution of $\mathrm{P} 95$ precipitation not associated with TCs with values ranging from $3.15 \%$ in 1983 to $22.20 \%$ in 1998 (Fig. 2). This also agrees with the results of [36], who found that while the intensity of summer precipitation in Sonora state increased significantly since 1977, in association with the +PDO phase, the monsoon season became shorter, resulting in a non-significant upward trend in precipitation [10] (Figs 2a-c). The linear trend of the percentage contribution of P95 associated with TCs was significantly increased $\left(0.86 \%\right.$ decade $^{-1}$, $\mathrm{p}<0.05$ ) during the period 1961-2000 (Fig. 2). This can be corroborated by the results of [37], who state that summer precipitation associated with TCs can contribute $50 \%$ to $71 \%$ to the annual cumulative precipitation of a region. In Fig. 2b, it can be seen that the contribution from P95 not associated with TC's in 1974, for the case in the mountain stations, had the highest record with $21.32 \%$, and for 2000 the greatest contribution from P95 associated with TC's with $15.24 \%$ occurred. The major contributions of P95 associated with TCs occurred in the time periods 1982$85,1987-90,1992$, and 2000, which seems to explain the significant increase in the intensity of P95 in mountain stations (Figs 2a and 2c) [37]. Also, according to [34, 38], the intensity of extreme summer precipitation in the plateau in northern Mexico (east of CNAM), has increased significantly, which is related to the greater contribution by $\mathrm{P} 95$ associated with TCs and with the respective occurrence of +PDO and -AMO anomalies (Figs 2a-d).

The percentage contribution of $\mathrm{P} 95$ in coastal stations was insignificant, mainly because the coastal areas are commonly affected by the passage of easterly waves and of TCs in mountain sites [11, 31]. For example, in the 1990s mountain sites received less intense precipitation associated with the monsoon; however, in this same area there were heavy precipitation events associated with TCs that resulted in large water contributions to the mountain area in the early 1990s, which was captured in the 10 large existing dams for agricultural activity. This transformed the 1990 s into one of the more prolific decades in history, which is documented in previous piezometer studies in the region [38]. Of 13 TCs recorded in the study area during the summer in the period 1961-2000, five made landfall and four occurred in the 1990s [39]. The effects of hurricanes with increasing precipitation, trends which have been identified in the period 19812000, were also reported by [40]: "Hurricanes of major intensity contributed in irrigation districts 063 and 065 with a hydraulic loading of $25 \mathrm{~m}$, which was registered for the first time in 30 years with a recovery of $1.2 \mathrm{~m}$ in 
the 1990s." These five hurricanes were Lidia (September 8-14, 1993, which occurred during a neutral event), Ismael (September 12-15, 1995, during a neutral event), Fausto (September 10-14, 1996, during a neutral event), and Isis (September 1-3, 1998, during a La Niña event), and only one cyclone event in the period September 18-30, 1982, which occurred during a strong summer El Niño. These results are similar to those reported by [33, 39], who found that there was a strong El Niño event in 1982 and La Niña events in late 1990. They also claim that extreme daily precipitation in a region tends to increase from anomalous effects in a La Niña event and not so much in an El Niño. According to the National Water Commission [41], in the period 1980-2003, Sinaloa was the second most affected state of Mexico - behind only Baja California Sur - by the passage of TCs. Although the state of Sonora is contiguous to Sinaloa, it was the $14^{\text {th }}$ most affected state. According to these statistics, with the values of AADEP associated with TCs (Figs 2a and 2b), potential damage such as floods, water erosion, loss of human life, and other effects in the study area can be estimated [5].

\section{Synoptic Conditions Associated with P95 of TCs}

Significant upward trends of the contribution of P95 in mountain sites appear to be related to the presence of TCs - especially in the 1990s. This explains the role played by synoptic conditions associated with $\mathrm{P} 95$ before and during the occurrence of TC events [42].

TC compounds that can generate events of P95 in southern Mexico are observed three days before the onset a) Z500an (isocontour) (m) y OLRan (shaded) $\left(\mathrm{W} \mathrm{m}^{-2}\right),-3 \mathrm{~d}$

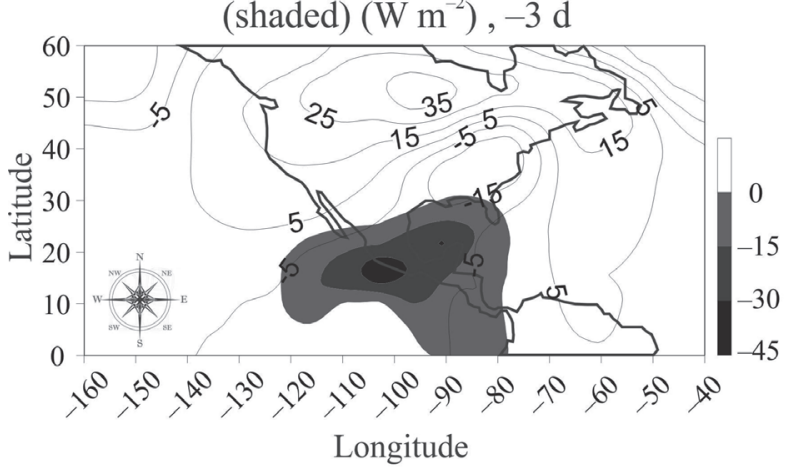

c) $\operatorname{SSTan}\left({ }^{\circ} \mathrm{C}\right), \mathrm{t}=1 \mathrm{~d}$

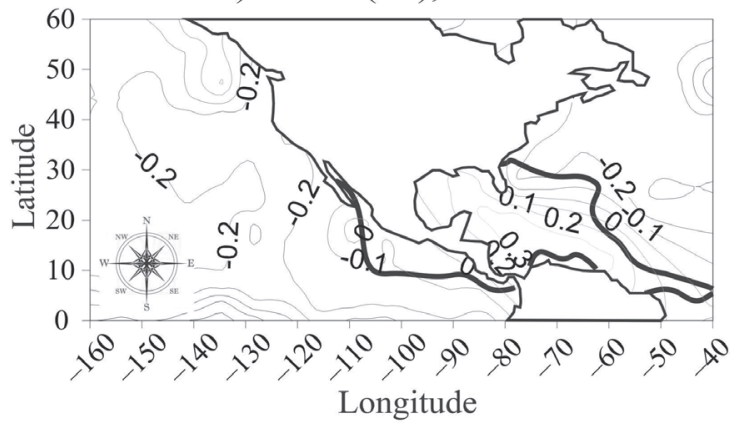

e) Stempan $\left({ }^{\circ} \mathrm{C}\right), \mathrm{t}=-14 \mathrm{~d}$

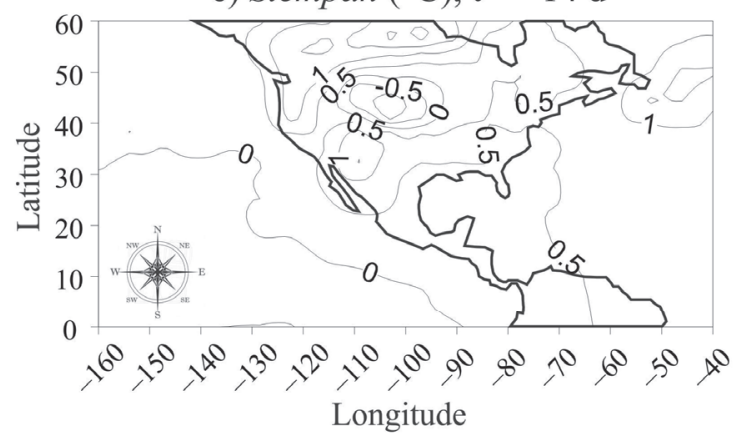

b) Z500an (isocontour) (m) y OLRan (shaded) $\left(\mathrm{W} \mathrm{m}^{-2}\right),-1 \mathrm{~d}$

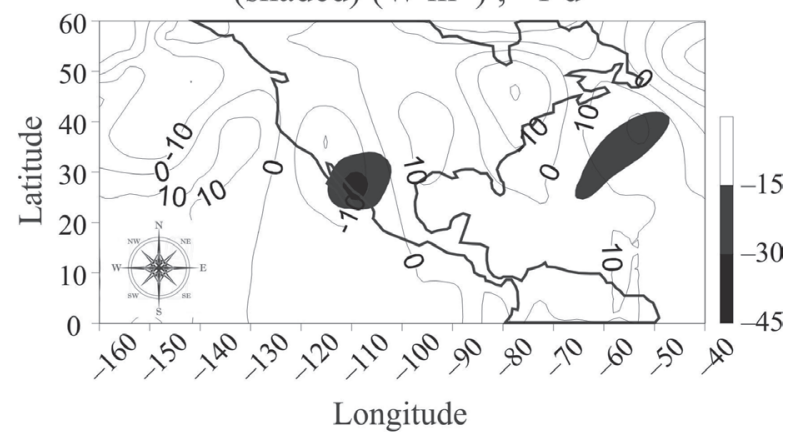

d) Mrelave (\%), $\mathrm{t}=1 \mathrm{~d}$

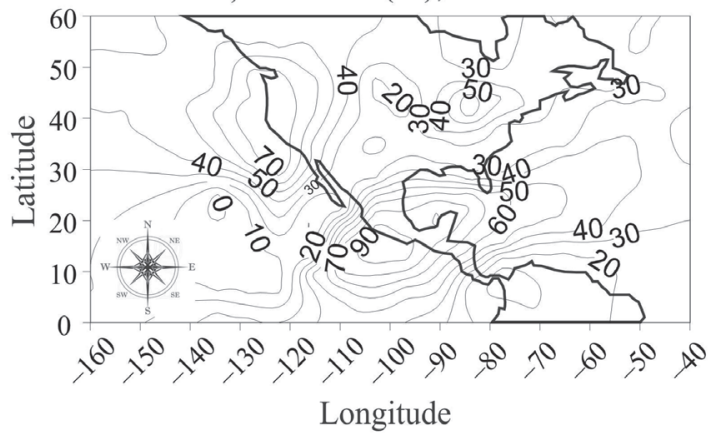

f) Stempan $\left({ }^{\circ} \mathrm{C}\right), \mathrm{t}=-7 \mathrm{~d}$

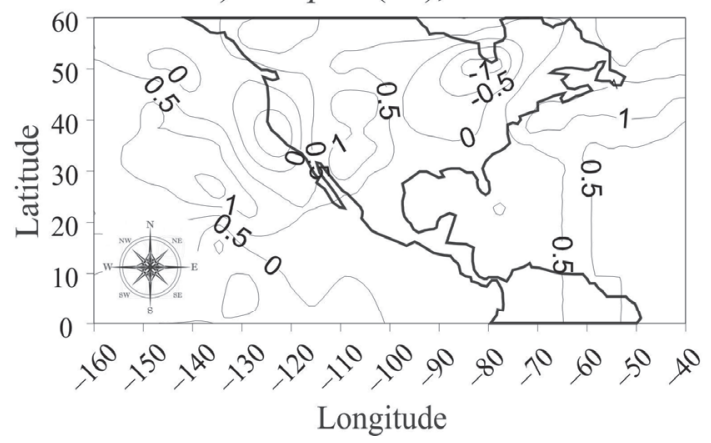

Fig. 3. Anomalies associated with P95 of TCs in 1961-2000. a) Geopotential height $\mathrm{Z500}_{\text {an }}$ (m) and outgoing longwave radiation OLR $\left(\mathrm{W} \mathrm{m}^{-2}\right)$ starting at $-3 \mathrm{~d}$; b) As a), but starting at $\left.-1 \mathrm{~d} ; \mathrm{c}\right)$ Sea surface temperature $\mathrm{SST}_{\text {an }}\left({ }^{\circ} \mathrm{C}\right)$ starting at $\left.1 \mathrm{~d} ; \mathrm{d}\right)$ Relative moisture Mrel ${ }_{\text {ave }}(\%)$, starting at $1 \mathrm{~d}$; e) Surface temperature Stemp $\mathrm{a}_{a n}\left({ }^{\circ} \mathrm{C}\right)$, starting at $-14 \mathrm{~d}$; and f) As e), but starting at $-7 \mathrm{~d}$. 
Table 2. Return periods of AADEP, probability distribution function of Gumbel and average annual P95 and P99 percentiles associated and not associated with TCs.

\begin{tabular}{|c|c|c|}
\hline $\begin{array}{l}\text { Return periods } \\
\quad \text { (years) }\end{array}$ & $\begin{array}{c}\text { Probability } \\
\text { (dimensionless) }\end{array}$ & $\begin{array}{c}\text { Average percentiles } \\
\text { annuals } P 95 \text { and } P 99 \\
\text { associated with AADEP } \\
\left(\mathrm{mm} \mathrm{yr}^{-1}\right)\end{array}$ \\
\hline 2 & 0.500 & $\begin{array}{c}P 95 \text { not associated with } \\
T C s=44.29\end{array}$ \\
\hline 5 & 0.800 & $\begin{array}{c}P 99 \text { not associated with } \\
T C s=73.77\end{array}$ \\
\hline 10 & 0.900 & $\begin{array}{c}P 95 \text { associated with } T C s \\
=47.65\end{array}$ \\
\hline 25 & 0.960 & $\begin{array}{c}P 99 \text { associated with } T C s \\
=74.86\end{array}$ \\
\hline 50 & 0.980 & \\
\hline 100 & 0.990 & \\
\hline 200 & 0.995 & \\
\hline 500 & 0.998 & \\
\hline
\end{tabular}

of extreme precipitation. They are generally observable in the configuration made for the contribution to events of high positive anomalies of $Z 500_{\text {an }}$ and negative anomalies of OLR ${ }_{\text {an }}$ [43] (Figs 3a-b). In the eastern equatorial Pacific (the El Niño 3 region), neutral negative La Niña anomalies $\left(-0.5^{\circ} \mathrm{C}\right.$; Fig. 3c) that favor cross-equatorial flows, westerly winds, and increased summer precipitation in southern Mexico [12, 43] add greater precipitation in the southern part of the CNAM [44]. From these results, it is clear that the system of TCs produces subsidence over the southwestern United States (partially reflected in the positive $\mathrm{Z}_{500}$ an pattern) and cooling in the eastern Pacific off the coast of Mexico [43] (Fig. 3c), thus increasing the magnitude of land-sea thermal contrast, which in turn increases the availability of moisture (Fig. 3d) for a distribution of storms along the Mexican Pacific [5, $39,42]$. The positive anomalies of Stemp $p_{a n}\left(>0.5^{\circ} \mathrm{C}\right)$ in northwestern Mexico suggest a positive land-sea thermal

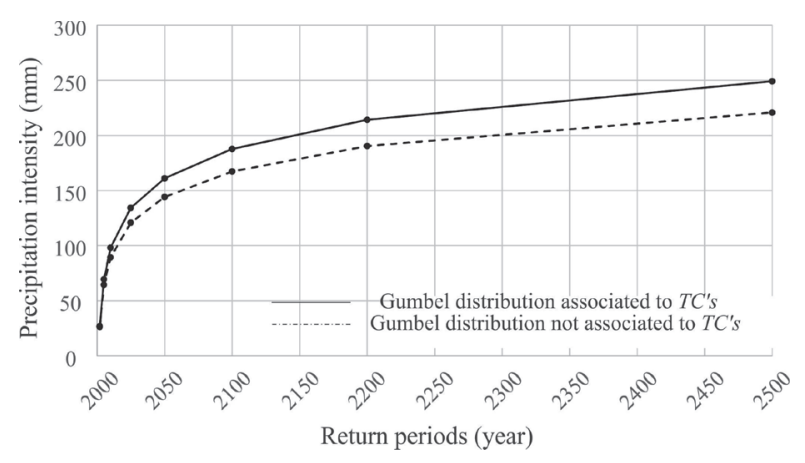

Fig. 4. Average return periods of AADEP (P95 and P99) associated and not associated with TCs in the CNAM in 19612000. contrast [3, 45] (Figs 3e-f). The synoptic conditions of Fig. 3 intensify the land-sea thermal contrast near the Gulf of California (Fig. 3b), which generates convective systems and heavy precipitation in the CNAM [5]. In the central region of the $C N A M$, the highest number of frequencies of P95 associated with TCs occurred in September, which originated when the intensity of the SST of the Western Hemisphere warm pool (WHWP) showed maximum anomalies of $S S T_{a n}>28.5^{\circ} \mathrm{C}$ (Fig. 3c) [3, 46]. Although this work is applied in the CNAM, the paper presents an approach that can serve as a diagnostic tool or application to hydrologists and other scientists of climate change at the continental or global levels, mainly by the effects of global warming.

\section{Return Periods of Average Annual Daily Extreme Precipitation (AADEP)}

Return periods, the probability distribution function of Gumbel and P95 and P99 of AADEP associated and not associated with TCs, can be seen in Table 2. P95 and P99 of AADEP associated with TCs (P95 $=47.65 \mathrm{~mm} \mathrm{yr}^{-1}$ and $\left.\mathrm{P} 99=74.86 \mathrm{~mm} \mathrm{yr}^{-1}\right)$ was greater than P95 and P99 of

a)
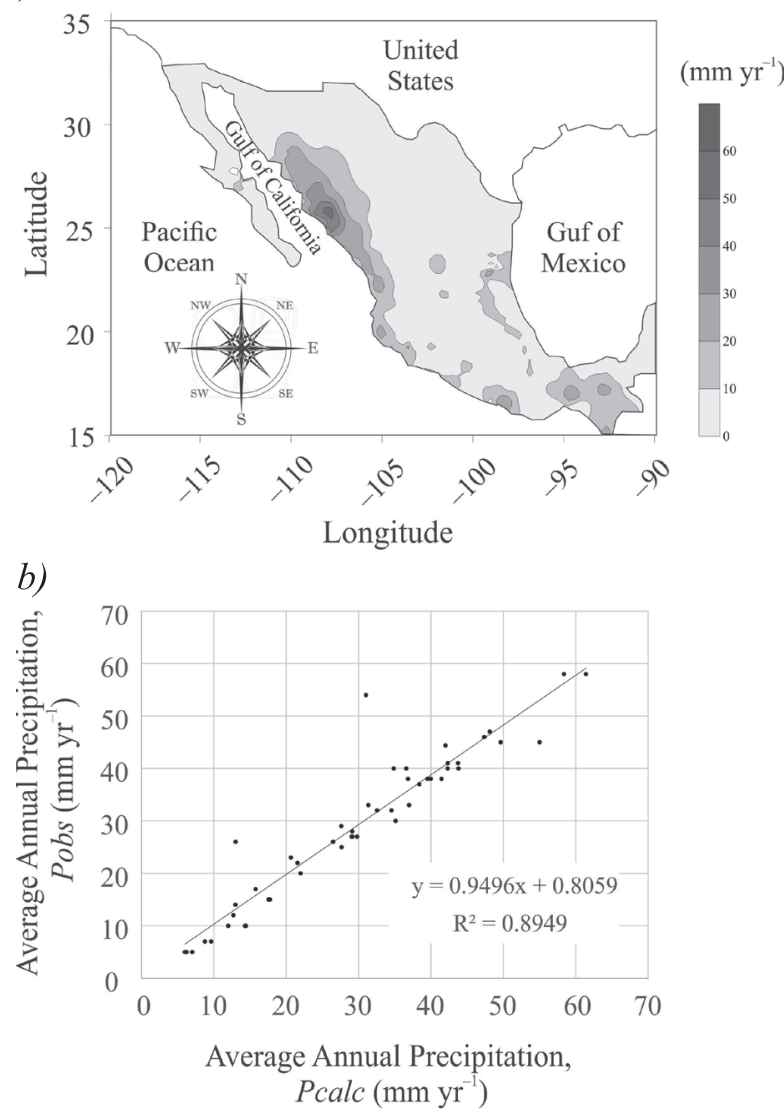

Fig. 5. a) Rate of AADEP registered during 13 TCs that affected the CNAM in 1981-2000 (from reanalysis of data from NOAA/ $\mathrm{CDC})\left(\mathrm{mm} \mathrm{yr}^{-1}\right)$, and b) Linear regression between $\mathrm{P}_{\text {calc }}$ and $\mathrm{P}_{\text {obs }}$ of AADEP of 13 TCs that affected the CNAM in 1981-2000. 
AADEP not associated with TCs (P95 $=44.29 \mathrm{~mm}_{\text {year }}{ }^{-1}$ and $\mathrm{P} 99=73.77 \mathrm{~mm} \mathrm{yr}^{-1}$ ), which is attributed to the fact that AADEP associated with TC's have shown an upward trend, especially in the 1990's, in which five of the 13 TC's in the 1990s made landfall in the CNAM.

Fig. 4 shows return periods for 2, 5, 10, 25, 50, 100, 200 , and 500 years and the intensity of precipitation associated and not associated with TCs [47]. As a forecast and according to the results, the highest intensities of AADEP are recorded in the return periods 25, 50, 100, 200, and 500 years, so the intensities of precipitation associated with TCs will be greater than those not associated with TCs (Fig. 4). This behavior was associated with the positive trend of continued growth of the intensity of the contribution of P95 in mountain stations and to simultaneous +PDO and -AMO anomalies mainly in the 1990's [34-35]. According to [47], knowing the return periods of extreme daily precipitation in a region can contribute to the development of mitigation and adaptation strategies to help assure food sustainability and decrease human casualties.

\section{Statistical Validation}

The Pearson Type III normality test produced coefficients of skewness of 0.09 and -0.04 , respectively, for $\mathrm{P}_{\text {calc }}$ and $\mathrm{P}_{\text {obs }}$. A linear regression between $\mathrm{P}_{\text {calc }}$ and $\mathrm{P}_{\text {obs }}$ (Figs 5a and 5b) had a correlation coefficient of $r=0.94$ and a determination coefficient $\mathrm{R}^{2}=0.89$. This is similar to what was reported by [6], who estimated a correlation of $\mathrm{r}=0.90$ between cumulative annual precipitation calculated using data from weather stations and observed bibliographical data.

\section{Conclusions}

There is a significant nonparametric upward trend in the intensity of P95 in mountain sites in 1961-2000. There was simultaneity in the +PDO and -AMO anomalies, which may be related to a greater contribution of P95 associated with TCs, mainly in the 1990's. In coastal sites, the contribution of P95 associated and not associated with TCs did not show significant trends. In the period 19812000, contributions of P95 associated with TCs were characterized by persistent negative anomalies of Stemp $\mathrm{an}_{\text {, }}$ which is similar to weak La Niña conditions. They were also characterized by the presence of anomalies of Stemp $>28.5^{\circ} \mathrm{C}$ in the WHWP area of the Caribbean Sea, as well as by a strong thermal land-sea contrast between northwestern Mexico and the southwestern United States and the eastern Pacific two weeks before the start of the TCs. The results of return periods in the CNAM are a new scientific contribution in the most important agricultural region of Mexico. There is an upward trend in AADEP in the period 1978-91, which is directly proportional to the precipitation regimen associated with TCs in the study area. The high AADEP are associated with the simultaneous occurrence of +PDO and -AMO anomalies since 1976. Since 1975, a decrease in the contribution from P95 not associated with TCs has been observed, with values from $3.15 \%$ in 1983 to $22.20 \%$ in 1998 and a steady increase of P95 intensity in mountain stations, resulting in a non-significant upward trend of monsoon P95. In the periods 1982-85, 1987-90, 1992, and 2000, the major contributions of P95 associated with TCs were observed, and these seem to explain the significant increase in the intensity of P95 in mountain resorts. The intensities of $\mathrm{P} 95$ associated with TCs will be greater than P95 not associated with TCs, and will be recorded in return periods of 25, 50, 100, 200, and 500 years. Although this work is applied in the CNAM, this paper presents an approach that can serve as a diagnostic tool or application to hydrologists and other scientists of climate change at continental or global levels, mainly by the effects of global warming.

\section{Acknowledgements}

Thanks are extended to the Department of Research and Graduate Studies, National Polytechnic Institute (SIP-IPN) for its support of the research projects with SIP registration Nos. 20151916 and 20150254.

\section{References}

1. MATTHEW R.L.G. Precipitación ciclónica como un riesgo natural, Tesis de doctorado de la Universidad Nacional Autónoma de México, México, D.F. 130, 2013.

2. CARLETON A.M., CARPENTER D.A., WESER P.J. Mechanisms of interannual variability of the southwest United States summer rainfall maximum. Journal of Climate 3, 999, 1990.

3. CEREZO M.R., CAVAZOS T., ARRITT R., TORRES A.A., SIECK K., NIKULIN G., MOUFOUMA O.W., SALINAS P.J.A. CORDEX-NA: Factors inducing dry/wet years on the North American Monsoon region. Int. J. of Climatol. 36, 824, 2016.

4. SÁNCHEZ G.D. Precipitaciones extremas y sus implicaciones en procesos de remoción en masa en la planificación urbana de Tampico, México. Cuadernos Geográficos, 48, 135, 2011.

5. HERNANDEZ A.J.J., MATYAS C.J. Tropical cyclone rainfall over Puerto Rico and its relations to environmental and storm-specific factors. Int. J. Climatol. 36, 2223, 2016.

6. LLANES C.O., NORZAGARAY C.M., MUÑOZ S.N.P., RUIZ G.R., TROYO D.E., ÁLVAREZ R.P. Hydroclimatic trends in areas with high agricultural productivity in northern Mexico. Polish Journal of Environmental Studies. 3 (24) 229, 2015.

7. GIOVANNETTONE J.P., BARROS A.P. A Remote sensing survey of the role of landform on the organization of orographic precipitation in Central and Southern Mexico. Journal of Hydrometeorology 9, 1257, 2008.

8. DIAZ S.C., SALINAS Z.C.A., HERNÁNDEZ V.S. Variability of rainfall from tropical cyclones in northwestern Mexico and its relation to SOI and PDO. Atmosfera 21 (2), 213, 2008.

9. MATÍAS M., MAGAÑA V. Regional aspects of prolonged meteorological droughts over Mexico and Central America. American Meteorological Society, 1175, 2009. 
10. WANG F., YANG S. Regional characteristics of long-term changes in total and extreme precipitations over China and their links to atmospheric-oceanic features. Int. J. Climatol. 2016. doi: $10.1002 /$ joc. 4737 .

11. GOCHIS D.J., JIMENEZ A.J., WATTS C.J., GARATUZA P.J., SHUTTLEWORTH W. J. Analysis of 2002 and 2003 warm-season precipitation from the North American monsoon experiment event rain gauge network, Mon. Weather Rev., 112, 2938, 2004.

12. DOUGLAS A.V., ENGLEHART P.J. A. Climatological Perspective of Transient Synoptic Features During NAME 2004. J. Clim. 20, 1947, 2007.

13. GOCHIS D.J., WATTS C.J., GARATUZAP.J., RODRIGUEZ J.C. Spatial and temporal patterns of precipitation intensity as observed by the NAME event rain gauge network from 2002 to 2004,J. Clim., 20, 1734, 2007.

14. WASH C.W.S., SILVESTRE E., PULACHE W. Tendencias de los extremos de lluvias cerca a la ciudad de Cusco y su relación con las inundaciones de enero del 2010, 2010.

15. TROYO D.E., MERCADO M.G., CRUZ F.A., NIETO G.A., VALDEZ C.R.D., GARCÍA H.J.L. Y MURILLO A.B. Análisis de la sequía y desertificación mediante índices de aridez y estimación de la brecha hídrica en Baja California Sur, noroeste de México. Investigaciones Geográficas, Boletín del Instituto de Geografía, UNAM, Num. 85, 66, 2014.

16. BRITO C.L., VIVONI E.R., GOCHIS D.J., FILONOV A., TERESHCHENKO I., MONZON C. An anomaly in the occurrence of the month of maximum precipitation distribution in northwest Mexico. Journal of Arid Environments 74 (2010) 531, 2010.

17. ENGLEHART P.J., DOUGLAS A.V. The role of eastern North Pacific tropical storms in the rainfall climatology of western Mexico, Int. J. Climatol., 21, 1357, 2001.

18. 1LARSON J., ZHOU Y., HIGGINS R.W. Characteristics of landfalling tropical cyclones in the United States and Mexico: Climatology and interannual variability, J. Clim., 18, 1247, 2005.

19. VELDEN C., HARPER B., WELLS F., BEVEN II J.L., ZEHR R., OLANDER T., MAYFIELD M., GUARD C., LANDER M., EDSON R., AVILA L., BURTON A., TURK M., KIKUCHI A., CHRISTIAN A., CAROFF P., MCCRONE P. The Dvorak Tropical Cyclone Intensity Estimation Technique: A Satellite-Based Method That Has Endured For Over 30 Years (PDF). Bulletin of the American Meteorological Society: 1195, 2006.

20. KENDALL M.G. Rank Correlation Methods, Charles Griffin, London, 1975.

21. HAMMER Ø. PAleontological STatistics Version 3.08 Reference manual, 243, 2015.

22. SEN P.K. Estimates of the regression coefficient based on Kendall's Tau, J. Am. Stat. Assoc., 63, 1379, 1968.

23. KOUTSOYIANNIS D. On the appropriateness of the Gumbel Distribution in modeling extreme rainfall, Proceedings of the ESF LESC Exploratory Workshop held at Bologna, Italy, October 24-25, 303, 2003.

24. GUTIÉRREZ L.J., VARGAS T.V., ROMERO R.M., PLÁCIDO DE LA CRUZ J.M., AGUIRRE B.M.J., SILVA E.H.T. Periodos de retorno de lluvias torrenciales para el estado de Tamaulipas, México. Investigaciones Geográficas, Boletín del Instituto de Geografía, UNAM, Num. 76, 20, 2011.

25. AGUILERAN.M.A. Estimación de funciones de distribución de probabilidad, para caudales máximos, en la región del Maule. Tesis de Licenciatura de la Universidad de TALCA, Facultad de Ciencias Forestales, Chile, 154, 2007.
26. REYNOLDS R.W., RAYNER N.A., SMITH T.M., STOKES D.C., WANG W. An improved in situ and satellite SST analysis for climate, J. Clim., 15, 1609, 2002.

27. KALNAY E., and 21 others. The NCEP/NCAR 40-year reanalysis project, Bull. Am. Meteorol. Soc., 77, 437, 1996.

28. VICH J.A.I., NORTE A.F., LAURO C. Análisis regional de frecuencias de caudales de ríos pertenecientes a cuencas con nacientes en la Cordillera de los Andes. Meteorológica Vol. 39, 3, 2014.

29. BUYTAERT W., CÉLLERI R., DE BIÈVRE B., CISNEROS F., WYSEURE G., DECKERS J., HOFSTEDE R. Human impact on the hydrology of the Andean páramos. EarthScience Reviews 79, 23, 2006.

30. HUNINK J.E., IMMERZEEL W.W., DROOGERS P. Análisis de Patrones Espaciales de Precipitación en la Provincia de Tungurahua. Gobierno Provincial de Tungurahua, Ecuador. 2013.

31. GIANNAKAKI P., MARTIUS O. Synoptic-scale flow structures associated with extreme precipitation events in northern Switzerland. Int. J. of Climatol. 36, 2497, 2016.

32. SANTACRUZ D.G. Estimación de la erosion hídrica y su relación con el uso de suelo en la cuenca del río Cahoacán, Chiapas, México. Aqua-LAC Vol. 3 (1), 45, 2011.

33. VILLARINI G., DENNISTON R.F. Short Communication Contribution of tropical cyclones to extreme rainfall in Australia. Int. J. Climatol. 36, 1019, 2016.

34. HOSSEIN T., WILLEMS P. Daily precipitation extremes in Iran: decadal anomalies and possible drivers. Journal of American Water Resources Association, 52 (2), 2016.

35. CRUZ R.J., RIVAS D., TEJEDA M.A. Variability of surface air temperature in Tampico, northeastern Mexico. Int. J. Climatol. 35, 3220, 2015.

36. ENGLEHART P., DOUGLAS A.V. Defining intraseasonal rainfall variability within the North American monsoon,J. Clim. 19, 4243, 2006.

37. NG B., WALSH K., LAVENDER, S. The contribution of tropical cyclones to rainfall in northwest Australia. Int. J. Climatol. 35, 2689, 2015.

38. GROSSMAN C.S., ZEHNDER J.A., STEFANOV W.L., LIU Y. ZOLDAK M.A. Urban modifications in a mesoscale meteorological model and the effects on near-surface variables in an arid metropolitan region. J. Appl. Meteor. 44, 1281, 2005.

39. TAN H., CAI R., CHEN J., HUANG R. Decadal winter drought in Southwest China since the late 1990s and its atmospheric teleconnection. Int. J. Climatol., 2016. doi: $10.1002 /$ joc. 4718 .

40. NORZAGARAY C.M., GARCÍA G.C., MUÑOZ S.P. Impacto natural-antropogénico en el flujo y los niveles piezométricos del acuífero del río Sinaloa. Revista Latinoamericana de Recursos Naturales 5 (3), 212, 2009.

41. COMISIÓN NACIONAL DEL AGUA CNA. Statistics on Water in Mexico, $2^{\text {nd }}$ ed., chap. 3-4, Comisión Nacional del Agua, Mexico City, 2004.

42. DE VRIES J., FELDSTEIN S.B., RIEMER M., TYRLIS E., SPRENGER M., BAUMGART M., FNAIS M., LELIEVELD J. Dynamics of tropical-extratropical interactions and extreme precipitation events in Saudi Arabia in autumn, winter and spring. Q. J. R. Meeorol. Soc. 2016. doi: $10.1002 / q j .2781$

43. MOORE T.W., DIXON R.W. Patterns in $500 \mathrm{hPa}$ geopotential height associated with temporal clusters of tropical cyclone tornadoes. Meteorol. Appl. 22, 314, 2015.

44. VIVONI E.R., GUTIÉRREZ J.H.A., ARAGÓN C.A., MÉNDEZ B.L.A., RINEHART A.J., WYCKOFF R.L., RODRÍGUEZ J.C., WATTS C.J., BOLTEN J.D., LAKSHMI 
V., JACKSON T.J. Variation of hydrometeorological conditions along a topographic transect in northwestern Mexico during the North American monsoon. Journal of Climate 20 (9), 1792, 2007.

45. HASANEAN H.M., ALMAZROUI M. Teleconnections of the tropical sea surface temperatures to the surface air temperatures over Saudi Arabia in summer season. Int. J. Climatol. 2016. doi: $10.1002 /$ joc. 4758
46. WANG C., ENFIELD D.B. A further study of the tropical Western Hemisphere warm pool, J. Clim., 16, 1476, 2003. 47. BARBOSA S.E., SÉRGIO L.S., SANTOS E., SILVA C.M. Estimating return periods for daily precipitation extreme events over the Brazilian Amazon. Theor. Appl. Climatol. 2015. doi: $10.1007 / \mathrm{s} 00704-015-1605-9$. 